\title{
28 Research Square \\ Respond to the COVID-19 pandemic: strategies comparison in six countries
}

\section{Haiqian Chen}

Southern Medical University

Leiyu Shi

Southern Medical University

Yuyao Zhang

Southern Medical University

Xiaohan Wang

Southern Medical University

Jun Jiao

Southern Medical University

Manfei Yang

Southern Medical University

Gang Sun ( $\sim$ gsun15@jhu.edu )

Johns Hopkins University https://orcid.org/0000-0002-9642-2886

Research

Keywords: COVID-19, containment strategy, mitigation strategy, countries comparison

Posted Date: May 4th, 2021

DOI: https://doi.org/10.21203/rs.3.rs-455879/v1

License: (c) (i) This work is licensed under a Creative Commons Attribution 4.0 International License.

Read Full License 


\section{Abstract}

Objective This study aimed to examine the effectiveness of the containment strategy and mitigation strategy taken by six countries.

Methods We extracted publicly available data from various official websites, summarized the strategies implemented in these six countries, and assessed the effectiveness of the prevention and control measures adopted by these countries.

Results Responding to an unprecedented COVID-19 pandemic, China, South Korea, and Singapore adopted containment strategies, and China and Singapore had a similar epidemic curve and the new daily cases. As of December 31, 2020, the new daily cases of China and Singapore were below less than 100 with the mortality rates per 100,000 population $0.3 \%$ and $0.5 \%$ respectively. But the new daily cases of South Korea as high as 1029 with the mortality rates per 100,000 1.8\%. In contrast, the United States, the United Kingdom, and France responded with mitigation strategies, and had similar epidemic curves and mortality rates per 100,000 population. The United States had up to 234,133 new confirmed cases per day and a mortality rate per 100,000 population was $107 \%$, while the UK had 56,029 new confirmed cases per day and a mortality rate per 100,000 population was $108 \%$, and France had 20,042 new cases per day, with a mortality rate per 100,000 population of $99 \%$.

Conclusions In response to the COVID-19 outbreak that is still spreading globally, countries can consider policy alternatives and novel solutions developed by other countries and adapt them base on their domestic circumstances and resources.

\section{Introduction}

The coronavirus disease 2019 (COVID-19) is continuing to spread worldwide. As of Feb 23, 2021, the COVID-19 outbreak has caused 112,222,860 confirmed cases, 2,483,930 death cases. The number of new cases outside China exceeded 290,000, the total of confirmed cases more than 110 million, and the total of death cases more than 2.47 million. ${ }^{1}$ However, fortunately, in the past year, at least 186 countries have implemented varying degrees of restrictions on population movement to slow the spread of the severe acute respiratory syndrome coronavirus and prevent health systems from becoming overwhelmed; these restrictions have amounted to lockdowns in 82 countries, resulting in a retreat in both new cases and the mortality rate. 2,3

At the beginning of the epidemic, different countries had different attitudes and strategies due to cultural differences, but now many issues reached a consensus. East Asian countries such as China placed more emphasis on non-pharmaceutical interventions in the early stage of the epidemic: containing the epidemic by means including "lockdown city", universal access to diagnostic techniques, screening for potential infections, and providing a saturation of isolation beds. Because of the low immunity to the COVID-19 and the recurrence of the epidemic, those in East Asia are now placing great emphasis on vaccine development and vaccination and hoping to contain the epidemic with the help of vaccines. In 
contrast, the developed countries such as Europe and the United States attached great importance to vaccine and drug development at the beginning of the epidemic, and have made relatively great progress in these areas. Now, Europe and the United States are beginning to focus on non-pharmaceutical control, but the global epidemic is still serious.

Despite the global availability of the COVID-19 vaccine, the importance of non-pharmaceutical interventions to contain the spread of the epidemic cannot be underestimated, given the current global vaccination management chaos, "vaccine shortage" and inequitable distribution. To compare the effects of different types of non-pharmaceutical interventions, this study selected China, South Korea, and Singapore, which were the countries in East Asia with earlier epidemics, and implemented containment strategies. Meanwhile, we also selected the United States, the United Kingdom, and France, which were the countries with more severe epidemics, and implemented mitigation strategies. We hoped that our findings will provide a policy reference for countries experiencing the impact of the COVID-19.

\section{Methods}

We extracted publicly available epidemiological data (including national population, total confirmed cases, daily new cases, total deaths, and daily new deaths) from official websites, including data from the National Health Commission of the People's Republic of China, and Johns Hopkins University \& Medicine Coronavirus Resource Center. To collect the available policy information and sort it out in containment and surveillance, healthcare, border control, and community and social. we searched national documents and responses to COVID-19 through various countries' government web-page, such as media announcements and governmental decrees of these six countries starting from the COVID-19 outbreak. We assessed the effectiveness of the COVID-19 strategies adopted by these countries through combining the strategies of the six countries with the daily new cases and mortality rate per 100,000 population.

\section{Results}

\section{National response to the COVID-19 pandemic China, South Korea and Singapore containment strategies}

China was the first country to report the COVID-19 infection. South Korea and Singapore, the next rapidly hit countries after China. At the beginning of the COVID-19 outbreak, with no immediate vaccines and antiviral medication for COVID-19, China being the epicenter of the outbreak swiftly swung into action in managing the epidemic. Typical measures include the use of existing traditional public health epidemic containment strategies of lockdown infectious areas, testing, isolation, quarantine, expanding the number of beds, physical distancing, and community containment. ${ }^{4}$

Similarly, South Korea and Singapore, the next two hit COVID-19 outbreak countries after China, fully utilized their experience from the MERS outbreak in 2015 and the SARS outbreak in 2003 respectively, in responding to COVID-19. South Korea, based on three core principles of openness, transparency, and 
creative innovation, was able to effectively implement the strategy of 3Ts of testing, tracing, and treatment. ${ }^{5}$ However, the Singapore government had constructed a three-pronged approach which includes travel, healthcare, and community measures to curb the spread of COVID-19. The major measures taken for COVID-19 in China, South Korea, and Singapore were summarized in Table 1 from containment, healthcare, border, and community and society. 
Table 1

The major measures taken for COVID-19 in China, South Korea and Singapore

\begin{tabular}{|c|c|c|c|}
\hline Measures & China & South Korea & Singapore \\
\hline $\begin{array}{l}\text { Containment } \\
\text { and } \\
\text { surveillance } \\
\text { measures }\end{array}$ & $\begin{array}{l}\text { Implementing strictly } \\
\text { the "Four early's" } \\
\text { measures of early } \\
\text { detection, early } \\
\text { reporting, early } \\
\text { isolation, and early } \\
\text { treatment. } \\
\text { (1) Early detection: } \\
\text { performing community } \\
\text { screening, setting up } \\
\text { temperature testing } \\
\text { points in } \\
\text { neighborhoods, } \\
\text { companies, shopping } \\
\text { malls and other public } \\
\text { places, and conducting } \\
\text { nucleic acid testing } \\
\text { screening for people } \\
\text { with clinical symptoms, } \\
\text { close contacts of } \\
\text { confirmed cases, and } \\
\text { people returning from } \\
\text { epidemic areas. } \\
\text { (2) Early reporting: } \\
\text { individual initiative } \\
\text { reporting, unit uniform } \\
\text { reporting, pharmacy } \\
\text { discovery reporting, } \\
\text { medical institution } \\
\text { reporting, joint } \\
\text { prevention and control } \\
\text { reporting. } \\
\text { (3) Early } \\
\text { isolation/quarantine: } \\
\text { self-quarantine at } \\
\text { home, centralized } \\
\text { medical isolation, and } \\
\text { centralized hospital for } \\
\text { observation. } \\
\text { (4) Early treatment: } \\
\text { clearly diagnose and } \\
\text { transfer to a designated } \\
\text { hospital as soon as } \\
\text { possible. }\end{array}$ & $\begin{array}{l}\text { "Three Ts" measures of fast } \\
\text { Testing, meticulous Tracing, and } \\
\text { appropriate Treatment. } \\
\text { (1) Fast testing, the Korean } \\
\text { government granted emergency } \\
\text { use authorization for testing kits } \\
\text { which helped to build a } \\
\text { foundation for large-scale } \\
\text { testing. And the introduction of } \\
\text { drive-through and walk-through } \\
\text { screening stations for sample } \\
\text { collection coupled with fast and } \\
\text { aggressive testing allowed early } \\
\text { detection of confirmed cases in } \\
\text { communities. } \\
\text { (2) Meticulous Tracing: the time } \\
\text { needed for epidemiological } \\
\text { investigations was also } \\
\text { significantly reduced thanks to } \\
\text { the utilization of ICT. } \\
\text { (3) Appropriate treatment: } \\
\text { confirmed cases are first } \\
\text { categorized by severity for } \\
\text { access to appropriate treatment. }\end{array}$ & $\begin{array}{l}\text { (1) At healthcare } \\
\text { facilities or through } \\
\text { contact tracing } \\
\text { confirmed cases were } \\
\text { based on clinical and } \\
\text { epidemiological } \\
\text { criteria, and } \\
\text { continuously update } \\
\text { as change of the } \\
\text { COVID-19 situation. } \\
\text { Doctors were also } \\
\text { allowed to test } \\
\text { patients who are } \\
\text { suspected for clinical } \\
\text { or epidemiological } \\
\text { reasons. } \\
\text { (2) All suspected and } \\
\text { confirmed cases were } \\
\text { immediately isolated } \\
\text { in hospital. } \\
\text { Asymptomatic close } \\
\text { contacts were } \\
\text { required to quarantine } \\
\text { for } 14 \text { days. Also, the } \\
\text { government launched } \\
\text { the "Trace Together" } \\
\text { APP to trace close } \\
\text { contacts. } \\
\text { (3) All public hospital } \\
\text { laboratories offer } \\
\text { PCR testing for } \\
\text { COVID-19 to increase } \\
\text { national diagnostic } \\
\text { capacity. }\end{array}$ \\
\hline
\end{tabular}




\begin{tabular}{|c|c|c|c|}
\hline Measures & China & South Korea & Singapore \\
\hline $\begin{array}{l}\text { Healthcare } \\
\text { measures }\end{array}$ & $\begin{array}{l}\text { (1) Pairing assistance, } \\
\text { mobilizing } 29 \text { provinces } \\
\text { to assist different cities } \\
\text { in Hubei province. From } \\
\text { January } 24 \text { to March } 8 \text {, } \\
2020, \text { a total } 346 \\
\text { medical teams and } \\
42,600 \text { medical } \\
\text { personnel were } \\
\text { mobilized to support } \\
\text { Hubei province. } \\
\text { (2) Makeshift hospitals, } \\
\text { establishing } \\
\text { Huoshenshan hospital, } \\
\text { Leishenshan hospital } \\
\text { and } 16 \text { Fangcang } \\
\text { shelter hospitals in } \\
\text { Hubei province, these } \\
\text { hospitals treated more } \\
\text { than } 12,000 \text { coVID-19 } \\
\text { patients. } \\
\text { (3) Classifying } \\
\text { management of "four } \\
\text { categories of } \\
\text { personnel". All } \\
\text { confirmed cases were } \\
\text { transferred to the } \\
\text { hospitals for } \\
\text { centralized treatment, } \\
\text { suspected cases, febrile } \\
\text { cases who might be } \\
\text { carriers, and close } \\
\text { contacts were sent to } \\
\text { designated venues for } \\
\text { isolation and medical } \\
\text { observation. }\end{array}$ & $\begin{array}{l}\text { (1) Whether public hospitals or } \\
\text { private hospitals were } \\
\text { committed to responding to the } \\
\text { COVID-19 outbreak. } \\
\text { (2) Launching Community } \\
\text { Treatment Centers (CTCs), from } \\
\text { March } 2 \text { to March } 26,2020 \text {, a } \\
\text { total of } 3,292 \text { patients were } \\
\text { admitted to } 17 \text { CTCs. } \\
\text { (3) Case categorization by } \\
\text { severity: asymptomatic, mild, } \\
\text { severe, and critical. } \\
\text { Asymptomatic patients and } \\
\text { patients with mild symptoms } \\
\text { were isolated at Residential } \\
\text { Treatment Centers or self- } \\
\text { quarantine, patients with } \\
\text { moderate symptoms were } \\
\text { hospitalized at Dedicated } \\
\text { Infectious Disease Hospitals, } \\
\text { patients with severe symptoms } \\
\text { or extremely severe symptoms } \\
\text { were hospitalized at } \\
\text { Government-designated } \\
\text { Isolation Hospitals. }\end{array}$ & $\begin{array}{l}\text { (1) Activating the } \\
\text { National Center for } \\
\text { Infectious Diseases } \\
\text { (NCID) for isolation } \\
\text { and treatment of } \\
\text { confirmed cases. } \\
\text { (2) Implementing the } \\
\text { "Public Health } \\
\text { Preparedness Clinics } \\
\text { program" - activated } \\
\text { more than } 800 \text { fever } \\
\text { clinics to treat fever } \\
\text { patients and provide } \\
\text { subsidies for citizens. } \\
\text { (3) The Big Box at } \\
\text { Jurong Mall was } \\
\text { transformed into a } \\
\text { community care } \\
\text { facility, accepting } \\
\text { mainly mild patients } \\
\text { for treatment and } \\
\text { isolation. } \\
\text { (4) Mild and } \\
\text { undifferentiated } \\
\text { persons were } \\
\text { instructed to self- } \\
\text { isolation at home. } \\
\text { Those with persistent } \\
\text { or worsening } \\
\text { symptoms are } \\
\text { advised to return to } \\
\text { the same doctor for } \\
\text { evaluation and } \\
\text { referral for testing. }\end{array}$ \\
\hline
\end{tabular}




\begin{tabular}{|c|c|c|c|}
\hline Measures & China & South Korea & Singapore \\
\hline $\begin{array}{l}\text { Border } \\
\text { control } \\
\text { measures }\end{array}$ & $\begin{array}{l}\text { (1) In the Guidelines on } \\
\text { Novel Coronavirus } \\
\text { Diagnosis and } \\
\text { Treatment emphasized } \\
\text { on the elements of the } \\
\text { port health quarantine, } \\
\text { increased the } \\
\text { epidemiological history } \\
\text { of travel or residence in } \\
\text { countries and regions } \\
\text { with serious outbreaks } \\
\text { abroad. } \\
\text { (2) Nucleic acid testing } \\
\text { were required to all } \\
\text { travelers or returning } \\
\text { residents entering from } \\
\text { all ports of entry. They } \\
\text { will be released from } \\
\text { quarantine if they do } \\
\text { not present with } \\
\text { symptoms and are } \\
\text { tested negative for } \\
\text { SARS-CoV-2 after } 14 \\
\text { days of quarantine. } \\
\text { (3) Implementing the } \\
\text { health declaration } \\
\text { system for people exit } \\
\text { and entry, strictly } \\
\text { carrying out entry } \\
\text { health quarantine, and } \\
\text { suspending the entry of } \\
\text { foreigners with valid } \\
\text { Chinese visas and } \\
\text { residence permits. }\end{array}$ & $\begin{array}{l}\text { (1) Adopted monitoring } \\
\text { measures such as special entry } \\
\text { procedures and mandatory } \\
\text { installation of a Self-Check } \\
\text { Mobile App to keep track and } \\
\text { monitor the health of inbound } \\
\text { travelers after arrival. } \\
\text { (2) Introduced mandatory } \\
\text { COVID-19 testing and two-week } \\
\text { quarantine for all inbound } \\
\text { travelers regardless of their port } \\
\text { of departure. } \\
\text { (3) Visa-free entry and visa- } \\
\text { waiver programs were also } \\
\text { suspended, with in addition to } \\
\text { countries that had not imposed } \\
\text { entry bans on Korean travelers. } \\
\text { (4) In late June, the Korean } \\
\text { government introduced country- } \\
\text { specific restrictions, temporarily } \\
\text { suspending visa issuance and } \\
\text { non-scheduled flights and } \\
\text { requiring submission of } \\
\text { negative PCR-test results for } \\
\text { issuing Korea-bound flight } \\
\text { tickets. }\end{array}$ & $\begin{array}{l}\text { Escalating border } \\
\text { control measures: } \\
\text { (1) Since Jan 3, 2020, } \\
\text { temperature and } \\
\text { health screening of } \\
\text { incoming travelers } \\
\text { from Wuhan and } \\
\text { extended to all } \\
\text { travelers since Jan } \\
29 \text {, is in place at all } \\
\text { ports of entry. } \\
\text { (2) Since Feb 1, } \\
\text { Singapore imposed } \\
\text { entry restrictions on } \\
\text { visitors from China; } \\
\text { returning residents } \\
\text { and long-term pass } \\
\text { holders are subject to } \\
\text { a 14-days quarantine. } \\
\text { (3) Since March 24, } \\
\text { prohibiting short-term } \\
\text { visitors and cruise } \\
\text { ship stops. } \\
\text { (4) Since March 27, } \\
\text { everyone who enters } \\
\text { Singapore without a } \\
\text { Stay Home Notice at } \\
\text { a designated facility } \\
\text { must wear an } \\
\text { electronic tracker. }\end{array}$ \\
\hline
\end{tabular}




\begin{tabular}{|c|c|c|c|}
\hline Measures & China & South Korea & Singapore \\
\hline $\begin{array}{l}\text { Community } \\
\text { and social } \\
\text { measures }\end{array}$ & $\begin{array}{l}\text { (1) Lockdown infection } \\
\text { areas: from Jan } 23 \text { to } \\
\text { April } 7,2020 \text {, lockdown } \\
\text { Wuhan city. Also, the } \\
\text { different varying } \\
\text { degrees of blockade } \\
\text { were imposed } \\
\text { nationwide. } \\
\text { (2) In China, all } \\
\text { provinces have } \\
\text { activated the highest- } \\
\text { level public health } \\
\text { emergency response. } \\
\text { Subsequently, many } \\
\text { tourist attractions were } \\
\text { temporarily closed, } \\
\text { suspending nationwide } \\
\text { tour operations and } \\
\text { overseas group travel } \\
\text { and free-travel } \\
\text { operations. } \\
\text { (3) School closures, } \\
\text { postponed school } \\
\text { opening or online } \\
\text { classes, extended } \\
\text { Spring Festival holidays } \\
\text { or working from home } \\
\text { to reduce population } \\
\text { moving. }\end{array}$ & $\begin{array}{l}\text { (1) No areas have been locked } \\
\text { down. } \\
\text { (2) Social Distancing- } \\
\text { Isolation/Quarantine, Stay-at- } \\
\text { home advisory, Closure of } \\
\text { Schools, Postpone School } \\
\text { Opening or Online Classes, } \\
\text { Restriction on using group } \\
\text { facilities, Restriction on group } \\
\text { events, and Curfew by district. }\end{array}$ & $\begin{array}{l}\text { (1) No areas have } \\
\text { been locked down. } \\
\text { (2) Before April 5, } \\
\text { 2020, the Singapore } \\
\text { government took } \\
\text { standing community } \\
\text { and social measures: } \\
\text { focused on health } \\
\text { education, limited } \\
\text { recreational } \\
\text { restrictions, } \\
\text { moratorium on large } \\
\text { events, } \\
\text { implementation of } \\
\text { leave orders and } \\
\text { home quarantine } \\
\text { orders for different } \\
\text { populations, } \\
\text { temperature testing. } \\
\text { (3) After April 5, 2020, } \\
\text { the government } \\
\text { introduced strict } \\
\text { measures: } \\
\text { suspending work, } \\
\text { school, and working } \\
\text { from home. }\end{array}$ \\
\hline
\end{tabular}

\section{United States, United Kingdom and France mitigation strategies}

Compared with China, South Korea and Singapore, which the countries occurred COVID-19 infections earlier, United States, United Kingdom and France seemed to be slower to respond to the COVID-19 outbreak and preferred to adopted mitigation strategies. The U.S. federal government's aggressive measures could date back to the declaration of a national emergency on March 13, 2020. Since then, the U.S. has adopted a combination of "containment" and "mitigation" strategies, with multiple channels and means of response and increasing support for prevention and control.

In the UK, the government did not taken more measures to control the COVID-19 epidemic before the midMarch, 2020. The British government began to implement mitigation strategies based on the theory of "herd immunity" until the outbreak in Italy and Spain were nearly out of control. Subsequently, the government further implemented more stringent measures such as city lockdown, school closures, and entertainment closures to stop the virus from spreading more widely. ${ }^{6}$ Likewise, France practiced lax mitigation strategies until mid-March. The French government was alerted only when the COVID-19 epidemic was raging, the number of confirmed cases and deaths increased dramatically. Thereafter, a 
strict mandatory stay at home was imposed and a state of national emergency was declared. ${ }^{7}$ The major measures taken for COVID-19 in United States, United Kingdom, and France were summarized in Table 2 from containment, healthcare, border, and community and society. 
Table 2

The major measures taken for COVID-19 in United States, United Kingdom and France

\begin{tabular}{|c|c|c|c|}
\hline Measures & United States & United Kingdom & France \\
\hline $\begin{array}{l}\text { Containment } \\
\text { and } \\
\text { surveillance } \\
\text { measures }\end{array}$ & $\begin{array}{l}\text { The United } \\
\text { States had a } \\
\text { slow start in } \\
\text { widespread } \\
\text { SARS-CoV-2 } \\
\text { testing. } \\
\text { (1) The Trump } \\
\text { administration } \\
\text { announced a } \\
\text { campaign to } \\
\text { conduct tests in } \\
\text { retail store } \\
\text { parking lots } \\
\text { across the } \\
\text { country, but this } \\
\text { was not widely } \\
\text { implemented. } \\
\text { (2) The NIH } \\
\text { launched a new } \\
\text { rapid test } \\
\text { development } \\
\text { program on April } \\
29,2020 \text {, Rapid } \\
\text { Acceleration of } \\
\text { Diagnostics. } \\
\text { (3) As of July } 1 \text {, } \\
\text { 2020, only four } \\
\text { states are using } \\
\text { contact tracing } \\
\text { apps as part of } \\
\text { their state-level } \\
\text { strategies to } \\
\text { control } \\
\text { transmission. } \\
\text { (4) As of August } \\
\text { 2020, the FDA } \\
\text { had granted } \\
\text { Emergency Use } \\
\text { Authorizations to } \\
\text { over } 200 \text { tests } \\
\text { for detecting } \\
\text { current or past } \\
\text { infection. }\end{array}$ & $\begin{array}{l}\text { (1) The United Kingdom } \\
\text { incorporated COVID-19 testing for } \\
\text { severe acute respiratory illness } \\
\text { (SARI) and ILI surveillances. } \\
\text { Starting in early June, mass } \\
\text { antibody testing was conducted. } \\
\text { (2) Individuals with suspected } \\
\text { mild symptoms of COVID-19 (new } \\
\text { continuous cough, fever or } \\
\text { anosmia) and all members of their } \\
\text { households to self-isolate for } 7 \\
\text { days and } 14 \text { days respectively, } \\
\text { and call NHS111 if required. } \\
\text { Patients with persistent and } \\
\text { severe symptoms were advised to } \\
\text { contact their general practitioner } \\
\text { (GP) or call emergency services. } \\
\text { (3) On May } 18,2020 \text {, the NHS } \\
\text { Testing and Tracing Service was } \\
\text { launched, whereby anyone in the } \\
\text { UK with symptoms can request an } \\
\text { antigen test via a dedicated } \\
\text { website. }\end{array}$ & $\begin{array}{l}\text { (1) French surveillance } \\
\text { system: according to the } \\
\text { COVID-19 surveillance } \\
\text { protocol, physicians } \\
\text { suspecting a COVID-19 } \\
\text { case have to contact } \\
\text { immediately either the } \\
\text { emergency hotline (SAMU- } \\
\text { Centre 15), if the patient is } \\
\text { seeking medical attention } \\
\text { from a general } \\
\text { practitioner, or a referring } \\
\text { infectious diseases } \\
\text { specialist at hospital level. } \\
\text { (2) Possible cases have to } \\
\text { be hospitalized, isolated } \\
\text { and cared for in one of the } \\
\text { 38 French referral } \\
\text { hospitals designated by } \\
\text { the Ministry of Health. } \\
\text { (3) Setting up case } \\
\text { definition and update with } \\
\text { the situation of the COVID- } \\
\text { 19. Contacts are traced } \\
\text { from the date of onset of } \\
\text { clinical symptoms in a } \\
\text { case. }\end{array}$ \\
\hline
\end{tabular}




\begin{tabular}{|c|c|c|c|}
\hline Measures & United States & United Kingdom & France \\
\hline $\begin{array}{l}\text { Healthcare } \\
\text { measures }\end{array}$ & $\begin{array}{l}\text { (1) Establishing } \\
\text { temporary } \\
\text { hospitals: the } \\
\text { first temporary } \\
\text { hospital in New } \\
\text { York was } \\
\text { completed on } \\
\text { March 28, 2020. } \\
\text { (2) Expanding } \\
\text { the number of } \\
\text { beds: on March } \\
\text { 28, 2020, the U.S. } \\
\text { medical ship } \\
\text { "Mercy" docked } \\
\text { in Los Angeles, } \\
\text { which can } \\
\text { provide 1,000 } \\
\text { beds. } \\
\text { (3) Appropriate } \\
\text { treatment: on } \\
\text { August 23, 2020, } \\
\text { the FDA } \\
\text { approved the use } \\
\text { of plasma from } \\
\text { recovered } \\
\text { individuals to } \\
\text { treat patients } \\
\text { with severe } \\
\text { COVID-19. } \\
\text { (4) From early } \\
\text { 2020, five or six } \\
\text { operating } \\
\text { primarily in the } \\
\text { U.S. began } \\
\text { vaccine research, } \\
\text { and COVID-19 } \\
\text { vaccine were } \\
\text { administered } \\
\text { from December } \\
\text { 14. }\end{array}$ & $\begin{array}{l}\text { (1) Established temporary critical } \\
\text { care hospitals: capacity was } \\
\text { upgraded at Belfast City Hospital } \\
\text { in Northern Ireland, NHS Louisa } \\
\text { Jordan was established in } \\
\text { Scotland, temporary critical care } \\
\text { NHS Nightingale hospitals were } \\
\text { built across England, and the } \\
\text { Dragon's Heart Hospital was set } \\
\text { up in Cardiff, Wales. } \\
\text { (2) Primary care practitioners were } \\
\text { advised to avoid face-to-face } \\
\text { assessment of suspected cases. } \\
\text { Instead, patients should be } \\
\text { immediately isolated and referred } \\
\text { to the local health authorities via a } \\
\text { hotline. }\end{array}$ & $\begin{array}{l}\text { (1) Relying on the military } \\
\text { to reinforce medical } \\
\text { forces. A field hospital } \\
\text { was established in the } \\
\text { Milus region of Alsace } \\
\text { with a total of } 30 \text { intensive } \\
\text { care beds on March } 25, \\
2020 \text {. Also, France } \\
\text { activated a medical high } \\
\text { speed train, Air Force } \\
\text { A330 and navy helicopters } \\
\text { to transport critically ill } \\
\text { patients in the east to } \\
\text { areas with less severe } \\
\text { outbreaks. } \\
\text { (2) Launching the White } \\
\text { Plan and Blue Plan to } \\
\text { coordinate all medical } \\
\text { resources, including } \\
\text { hospitals, clinics, and } \\
\text { social security agencies. } \\
\text { Also, retired health care } \\
\text { workers and medical } \\
\text { students have also been } \\
\text { mobilized to join the fight } \\
\text { against the epidemic. }\end{array}$ \\
\hline
\end{tabular}




\begin{tabular}{|c|c|c|c|}
\hline Measures & United States & United Kingdom & France \\
\hline $\begin{array}{l}\text { Border } \\
\text { control } \\
\text { measures }\end{array}$ & $\begin{array}{l}\text { (1) Public health } \\
\text { screening at } \\
\text { Major Airport on } \\
\text { January 22, } \\
2020, \text { and } 11 \\
\text { Airports added to } \\
\text { Screening Watch } \\
\text { List. } \\
\text { (2) Suspension } \\
\text { of access to the } \\
\text { United States: } \\
\text { beginning March } \\
21,2020, \text { U.S. } \\
\text { border crossings } \\
\text { closed to travel } \\
\text { other than "core } \\
\text { essential travel". } \\
\text { (3) On March 13, } \\
\text { 2020, the federal } \\
\text { government } \\
\text { escalated from a } \\
\text { public health to a } \\
\text { national } \\
\text { emergency, and } \\
\text { since March } 16 \\
\text { all states had } \\
\text { declared a state } \\
\text { of emergency or } \\
\text { a public health } \\
\text { emergency. }\end{array}$ & $\begin{array}{l}\text { (1) In March 2020, the UK went } \\
\text { into lockdown. The government } \\
\text { banned all non-essential travel. } \\
\text { (2) Travelers entering the UK } \\
\text { would have to self-isolate for } 14 \\
\text { days upon arrival to help slow the } \\
\text { spread of COVID-19. } \\
\text { (3) From October onwards, varying } \\
\text { levels of lockdown were imposed } \\
\text { in England. }\end{array}$ & $\begin{array}{l}\text { (1) Emmanuel Macron } \\
\text { announced a lockdown } \\
\text { period from March } 17 \text { to } \\
\text { May 11,2020: ban on all } \\
\text { travel except relating to } \\
\text { professional activity, } \\
\text { buying essential goods, } \\
\text { health or family reasons } \\
\text { or brief individual } \\
\text { exercise. } \\
\text { (2) From March 17, France } \\
\text { closed its borders for } 30 \\
\text { days. The government } \\
\text { advised long-term } \\
\text { residents who have lived } \\
\text { abroad to avoid } \\
\text { international travel or } \\
\text { return to France for the } \\
\text { next } 30 \text { days. } \\
\text { (3) Macron addressed that } \\
\text { France entered a second } \\
\text { nationwide lockdown } \\
\text { from October } 30,2020 \text {. }\end{array}$ \\
\hline
\end{tabular}




\begin{tabular}{|c|c|c|c|}
\hline Measures & United States & United Kingdom & France \\
\hline $\begin{array}{l}\text { Community } \\
\text { and social } \\
\text { measures }\end{array}$ & $\begin{array}{l}\text { (1) Many } \\
\text { additional } \\
\text { mitigation } \\
\text { policies have } \\
\text { been enacted at } \\
\text { the state level: } \\
\text { school closures, } \\
\text { large gathering } \\
\text { bans, non- } \\
\text { essential } \\
\text { business } \\
\text { closures, stay-at- } \\
\text { home orders, } \\
\text { bar/restaurant } \\
\text { limits, and } \\
\text { primary election } \\
\text { postponements. } \\
\text { (2) Lockdown } \\
\text { infection areas: } \\
\text { on December } 3 \text {, } \\
\text { 2020, locked } \\
\text { down the city of } \\
\text { Los Angeles, } \\
\text { USA. } \\
\text { (3) Mask } \\
\text { mandates have } \\
\text { been } \\
\text { implemented: as } \\
\text { of early August, } \\
\text { just over half of } \\
\text { states require } \\
\text { individuals to } \\
\text { wear a mask in } \\
\text { public, although } \\
\text { in some states } \\
\text { without a } \\
\text { statewide } \\
\text { mandate local } \\
\text { authorities have } \\
\text { mask wearing } \\
\text { ordinances }\end{array}$ & $\begin{array}{l}\text { (1) Implementing a series of TV, } \\
\text { radio and social media campaigns } \\
\text { and recommendations for } \\
\text { behavior change in the general } \\
\text { public. } \\
\text { (2) The stringency of containment } \\
\text { measures escalated: the closure } \\
\text { of non-essential services on } \\
\text { March } 16, \text { follow by a lockdown } \\
\text { on March 23. (3) Closures and } \\
\text { restrictions: schools closure, non- } \\
\text { essential activities were } \\
\text { prohibited. Individuals were } \\
\text { required to stay at home and work } \\
\text { from home where possible, with } \\
\text { only an hour of exercise, trips for } \\
\text { food shopping and medication } \\
\text { allowed per day, and a social } \\
\text { distancing measure of } 2 \text { m. } \\
\text { (4) Mask mandates have been } \\
\text { implemented when people take } \\
\text { public vehicles. }\end{array}$ & $\begin{array}{l}\text { (1) The first nationwide } \\
\text { lockdown: bans on } \\
\text { gatherings, closure of } \\
\text { most public } \\
\text { establishments, and } \\
\text { closure of schools and } \\
\text { institutes of higher } \\
\text { education. } \\
\text { (2) Progressive lifting of } \\
\text { lockdown restrictions: all } \\
\text { gatherings, meetings, } \\
\text { activities, travel and usage } \\
\text { of public transport were } \\
\text { required to respect social } \\
\text { distancing rules. } \\
\text { (3) Masks made } \\
\text { mandatory in an extended } \\
\text { range of public places. } \\
\text { (4) Curfews and second } \\
\text { national lockdown: with } \\
\text { similar restrictions to the } \\
\text { first national lockdown } \\
\text { except that primary- and } \\
\text { secondary school children } \\
\text { can still attend school. }\end{array}$ \\
\hline
\end{tabular}

\section{Epidemiological trends and population mortality rates of COVID-19 in six countries}

As shown in Figs. 1, 2 and 3, China, South Korea, and Singapore experienced large COVID-19 outbreaks and initially responded with a containment strategy, and China and Singapore had a similar epidemic curve and the number of new confirmed COVID-19 cases by December 31, 2020. In terms of mortality rate per 100,000 population, China's rate was $0.3 \%$, South Korea's rate was $1.8 \%$, and Singapore's rate was $0.5 \%$. As of December 31,2020 , especially in China and Singapore, which maintained a low mortality rate 
per 100,000 population no more than $1 \%$, and new confirmed cases per day only 87 and 30 respectively. However, new confirmed cases per day in Korea were as high as 1029.

Figures 4, 5 and 6 showed that the United States, the United Kingdom, and France, which responded with a mitigation strategy when the COVID-19 pandemics emerged, had similar epidemic curves and mortality rates per 100,000 population by December 31, 2021. Among them, as of December 31, 2020, the United States had up to 234,133 new confirmed cases per day and a mortality rate per 100,000 population was $107 \%$, while the UK had 56,029 new confirmed cases per day and a mortality rate per 100,000 population was $108 \%$, and France had 20,042 new cases per day, with a mortality rate per 100,000 population of $99 \%$.

Whether in the new confirmed cases per day, or the mortality rate per 100,000 population, the difference is significantly remarkable between China, South Korea, and Singapore, which implemented containment strategies, and the United States, United Kingdom, and France, which taken mitigation strategies.

Figures 2, 4, 5 and 6 showed that South Korea, the United States, the United Kingdom, and France all had a similar epidemic curve by December 31,2020. Nevertheless, South Korea had a case fatality rate approximately one-percent of that of countries adopting a mitigation strategy. (South Korea: $1.8 \%$ vs. the United States: 107\%; United Kingdom: 108\%; and France: 99\%, by December 31, 2020).

\section{Discussion}

In response to the COVID-19 epidemic that is ravaging the world, different countries have employed various strategies for controlling the COVID-19 pandemic based on their national situations. These epidemic control strategies can be classified into two types: one type is a containment strategy, other is a mitigation strategy. A containment strategy focuses on disease prevention and the control of infectious diseases from three aspects: infectious sources, transmission routes, and susceptible populations. ${ }^{8}$ It aimed to break the chain of transmission through a combination of aggressive test-and-isolate policy (identify and isolate all infectious persons, including those with mild illness) and social distancing measures. $^{9}$

Whereas, a mitigation strategy focuses on reducing the rate of transmission, asserting that the spread of COVID-19 cannot be completely interrupted and can only be slowed when the population forms an adequate immune barrier and the intensity of the epidemic decreases to become a seasonal infection such as influenza. ${ }^{8}$ It aimed to reduce death tolls by focusing on the medical care of severe cases while relying on social distancing to flatten the curve of epidemic impact on healthcare systems. ${ }^{9}$

\section{Containment strategy}

China, South Korea, and Singapore, the representative countries adopted containment strategies, achieved remarkable results in the fight against the COVID-19 epidemic and all of their case-fatality maintain at a low level. This seems to be inextricably linked to their national cultures and the prevention and control measures they have adopted. 
COVID-19 outbreak of China was concentrated in the early stage, in the face of a previously unknown virus and a new public health threat, the great characteristic of China that a leadership system-the Epidemic Prevention and Control Headquarters System (EPCHS)-was set up at all levels, enabling a whole-of-government response and accountability to address the epidemic. ${ }^{10}$ Moreover, responding to a dramatic increase in cases and inadequate health resources, a series of strict containment strategies were imposed in China, including lockdown Wuhan city, mobilizing healthcare workers from other provinces to support Hubei (the province where resides Wuhan, the former epicenter), erecting Huoshenshan hospital, Leishenshan hospital, and 16 Fangcang shelter hospitals, classifying management of "four categories of personnel", and implementing "four early's" measures(early detection, early diagnosis, early isolation, and early treatment) to the community, even to individuals. After the battle of Wuhan, the subsequent outbreaks of sporadic epidemics and even localized clusters in Harbin of Heilongjiang, Shulan of Jilin, Xinfadi of Beijing, and Qingdao of Shandong all proved to be the most valuable window of time for China's full-scale nucleic acid testing.

Singapore, one of the first countries affected by COVID-19, adopted a national strategy for the pandemic which emphasized preparedness through a whole-of-nation approach. The most characteristics of containment strategy was that implemented a three-pronged approach of reducing spread from imported cases, detecting and isolating cases early, and emphasizing and supporting social responsibility to control the COVID-19 outbreak. ${ }^{11}$ In concrete practice, Singapore maximized the detection of suspected patients through public prevention of clinic networks and strictly enforced home isolation orders for patients with mild symptoms. ${ }^{12}$

South Korea, fully utilized its experience from the MERS outbreak in 2015, quickly scaling up testing to detect cases as early as possible in responding to the COVID-19 outbreak. ${ }^{13}$ Hence, the Korean government established more than 600 screening sites that capable of performing SARS-CoV-2 nucleic acid tests including public health-care clinics, drive-through centers, and walk-in screening sites. In South Korea, more than 15,000 screenings can be performed daily. Based on the triage system, patients with mild illnesses, especially those younger than 50 years, were instructed to stay in designated locations or at home rather than in hospitals. Other measures include school closures, locking down areas with severe outbreaks, and banning gatherings. ${ }^{14}$ But the objective of Korea's COVID-19 response strategy was to prevent the spread of the disease, protect public health, and keep the society and economy open so that daily life can continue. ${ }^{15}$ The core intervention in China, Singapore, and South Korea has been timely detection and management of suspected and confirmed cases and identification and management of their close contacts.

\section{Mitigation strategy}

The United States, the United Kingdom, and France as the typical countries that implementing mitigation strategies, compared with the countries adopting containment strategies, the COVID-19 outbreaks seem to be worse. As we all know, the U.S. is a wealthy country, armed with numerous high technological and biological tools to fight the COVID-19 outbreak. ${ }^{4}$ However, for what it's worth, the United States had the 
highest number of cases and deaths globally, highlighted by a lack of national leadership and a patchwork of state and local government responses but perhaps most detrimental is the division of society along partisan lines. ${ }^{16,17}$ Of course, there is also a primary issue in the U.S. has been the poor coordination of testing efforts and inability to test at-scale to provide comprehensive national (or even state) surveillance. ${ }^{18}$ Although the U.S. has begun a series of mitigation measures, such as all states had declared a state of emergency or a public health emergency, school closures, large gathering bans, nonessential business closures, stay-at-home orders, bar/restaurant limits, primary election postponements, and mask-wearing ordinances.

The United Kingdom declared the COVID-19 epidemic as influenza in the early stage, emphasizing that COVID-19 was unlikely to be completely interrupted and focusing mainly on the treatment of severe cases, most of which had mild symptoms. Matters worsened when Vallance initially rejected "eyecatching measures" such as stopping mass gatherings or closing schools. To widespread criticism, he floated an approach to "build up some degree of herd immunity" founded on an erroneous view that the vast majority of cases would be mild, like influenza. ${ }^{19}$ With Italy, Spain, and France had taken firm public health action and was in full lockdown, The UK was also starting to work on the prevention of the disease. Policies were to be based on the science, with an initial focus on containment, involving the identification of people infected with SARS-Cov-2, contact tracing, and isolation of people with proven exposure. ${ }^{20}$ Also a package of intensive interventions put in place including physical distancing, with a particular impact on leisure activities; workers being asked to work from home where possible; shielding of both older individuals (70 years) and people in high-risk groups of all ages; school closures; and selfisolation of symptomatic individuals. ${ }^{21}$

At the beginning of the outbreak, the COVID-19 epidemic did not have a significant impact on France, although with the dramatic increase in new COVID-19 cases, France implemented strict intervention strategies in March 2020, such as implementing strict national lockdown, improving the level of COVID-19 detection, fully protecting the medical workforce, and strengthening research and clinical treatment methods for COVID-19. However, the government's early dissemination was intended to reassure the population that the probability of the virus spreading in France was low. Moreover, following the rapid spread of the virus in France towards the end of February, the government, totally unprepared for a pandemic. ${ }^{22}$ This was one of the reasons for the poor control of the epidemic in France, the sharp increase in daily COVID-19 cases and the high mortality rate per 100,000 population (as of December 31 , 2020 , the mortality rate per 100,000 population was $99 \%$ ).

\section{Containment versus mitigation strategy}

This study found that countries implementing the containment strategy appeared to have better outcomes than those implementing mitigation, whether in terms of trends in daily case growth or curves in mortality rates per 100,000 population. Although each country has implemented a series of nonpharmaceutical interventions at four levels of the epidemic: containment and surveillance, healthcare, border control, and community and society. However, China, South Korea, and Singapore, due to their 
experience with previous MERS and SARS epidemics, responding quickly, implementing strict interventions, and control the spread of the epidemic to keep the daily new cases and mortality rate per 100,000 population low. Furthermore, with the inoculation of the COVID-19 in 2021, strict nonpharmaceutical interventions are still being implemented. In contrast, the United States, the United Kingdom, and France, due to their lax approach at the beginning of the epidemic, made the subsequent fight against the epidemic more difficult. Although a series of non-pharmaceutical interventions were implemented, and these countries have initiated vaccination programs for COVID-19, the results seem to be less than satisfactory.

\section{Conclusion}

Until the vaccine is globally available and effective, we still need to address the current COVID-19 epidemic with non-pharmacological measures in four aspects: containment and surveillance, healthcare, border control, and community and society to avoid further damage. Countries can consider policy alternatives and novel solutions developed by other countries and adapt them base on their domestic circumstances and resources.

\section{Declarations}

\section{Ethics approval and consent to participate}

Not applicable.

\section{Consent for publication}

Not applicable.

\section{Availability of data and materials}

All data generated or analyzed during this study are included in this published article.

\section{Competing interests}

The authors have no conflicts of interest to declare.

\section{Funding}

The National Social Science Fund of China (No. 16BGL184).

\section{Authors' contributions}

Haiqian Chen and Gang Sun conceived the paper. Haiqian Chen, Yuyao Zhang, Xiaohan Wang, Manfei Yang, and Jun Jiao collected the data. Haiqian Chen drafted the manuscript. Leiyu Shi, Yuyao Zhang, Xiaohan Wang, Manfei Yang and Jun Jiao revised the manuscript. Gang Sun contributed to the critical 
revision of the manuscript for important intellectual content and approved the final version of the manuscript. All authors have read and approved the final manuscript. Haiqian Chen and Gang Sun are the study guarantors.

\section{Acknowledgments}

The authors gratefully acknowledge the financial supports of the National Social Science Fund of China (No. 16BGL184), thank all study participants who have been involved and contributed to the procedure of data collection.

\section{References}

1. COVID-19 CORONAVIRUS PANDEMIC. https://www.worldometers.info/coronavirus/\#countries.

2. Middelburg RA, Rosendaal FR. COVID-19: How to make between-country comparisons. International journal of infectious diseases : IJID : official publication of the International Society for Infectious Diseases. Jul 2020;96:477-481.

3. Emeline Han, Melisa Mei Jin Tan, Eva Turk, et al. Lessons learnt from easing COVID-19 restrictions an analysis of countries and regions in Asia Pacific and Europe. Lancet 2020;396:1525-1534.

4. Olufadewa, II, Adesina MA, Ekpo MD, et al. Lessons from the coronavirus disease 2019 (COVID-19) pandemic response in China, Italy, and the U.S.: a guide for Africa and low-and-middle-income countries. Global health journal. Feb 92021.

5. COVID-19 and Korea's Response. https://www.youtube.com/watch? $v=s F S r 6 t o s D k E \& f e a t u r e=y o u t u . b e$.

6. Analysis of the plight of epidemic prevention and control in Europe. https://www.fx361.com/page/2020/0424/6598987.shtml.

7. Guoqing W. A review of the new crown pneumonia outbreak in France and its mirroring implications. 2020;26:41-46.

8. Zhang $X$, Wang Y. Comparison between two types of control strategies for the coronavirus disease 2019 pandemic. Journal of infection in developing countries. Jul 31 2020;14(7):696-698.

9. Chen YH, Fang CT. Mortality from COVID-19: A cross-country comparison of containment versus mitigation strategy. Journal of the Formosan Medical Association = Taiwan yi zhi. Nov 2020;119(11):1710-1712.

10. Ning Y, Ren R, Nkengurutse G. China's model to combat the COVID-19 epidemic: a public health emergency governance approach. Global Health Research and Policy. 2020;5(1).

11. Chua AQ, Tan MMJ, Verma M, et al. Health system resilience in managing the COVID-19 pandemic: lessons from Singapore. BMJ global health. Sep 2020;5(9).

12. JohnE.L.Wong, YeeSinLeo, ChorhChuanTan. COVID-19 in Singapore-Current Experience Critical Global Issues That Require Attention and Action. Jama. 2020;323:1243-1244. 
13. Kasai T. What we must do to contain COVID in 2021. Lessons for the Western Pacific region from 2020. 2021; https://asia.nikkei.com/Opinion/What-we-must-do-to-contain-COVID-in-2021.

14. Li Z, Chen Q, Feng L, et al. Active case finding with case management: the key to tackling the COVID19 pandemic. The Lancet. 2020;396(10243):63-70.

15. Korea GotRo. All about Korea's Response to COVID-19. 2020;

http://www.mofa.go.kr/viewer/skin/doc.html?

$f n=20201021031300238$.pdf\&rs=/viewer/result/202103.

16. Staff SN. United States strains to act as cases set record. Science. 2020;368:17-18.

17. Lu G, Razum O, Jahn A, et al. COVID-19 in Germany and China: mitigation versus elimination strategy. Global health action. Jan 1 2021;14(1):1875601.

18. Bergquist S, Otten T, Sarich N. COVID-19 pandemic in the United States. Health policy and technology. Dec 2020;9(4):623-638.

19. Scally G, Jacobson B, Abbasi K. The UK's public health response to covid-19. Bmj. May 15 2020;369:m1932.

20. Hunter DJ. Covid-19 and the Stiff Upper Lip - The Pandemic Response in the United Kingdom. The New England journal of medicine. 2020;382(16):e31.

21. Davies NG, Kucharski AJ, Eggo RM, et al. Effects of non-pharmaceutical interventions on COVID-19 cases, deaths, and demand for hospital services in the UK: a modelling study. The Lancet Public Health. 2020;5(7):e375-e385.

22. Or Z, Gandre C, Durand Zaleski I, Steffen M. France's response to the Covid-19 pandemic: between a rock and a hard place. Health economics, policy, and law. Mar 5 2021:1-13.

\section{Figures}

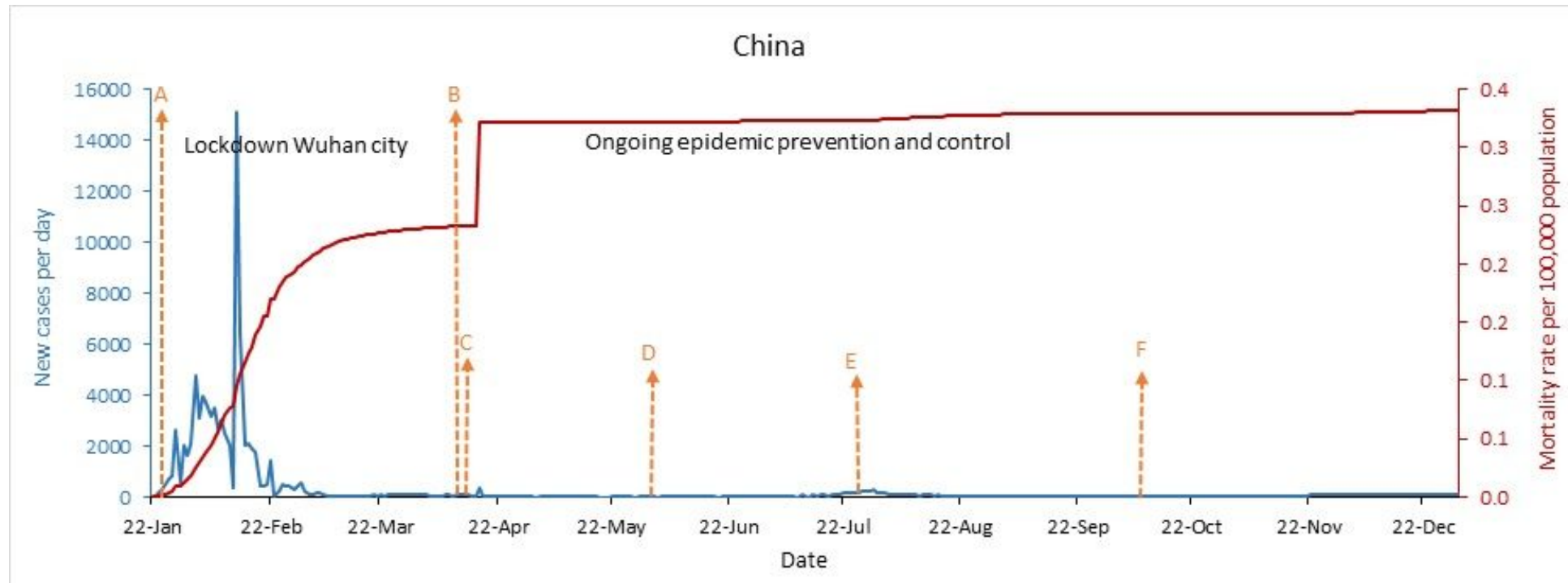


Figure 1

China's COVID-19 epidemic curves and population mortality rate. Note: A Beginning of January 23, 2020, lockdown Wuhan city, all provinces or regions initiated a Class 1 Response Public Health Emergency. B Beginning of April 8, lifting lockdown of Wuhan city, and entering the phase of ongoing epidemic prevention and control. C On April 9, a COVID-19 cluster was detected in Heilongjiang Province. D On June 4, a COVID-19 cluster emerged at Xinfadi Market in Beijing. E On July 26, COVID-19 cases mostly from outbreaks in Xinjiang and Liaoning. F On October 11, a COVID-19 cluster was appeared in Qingdao.

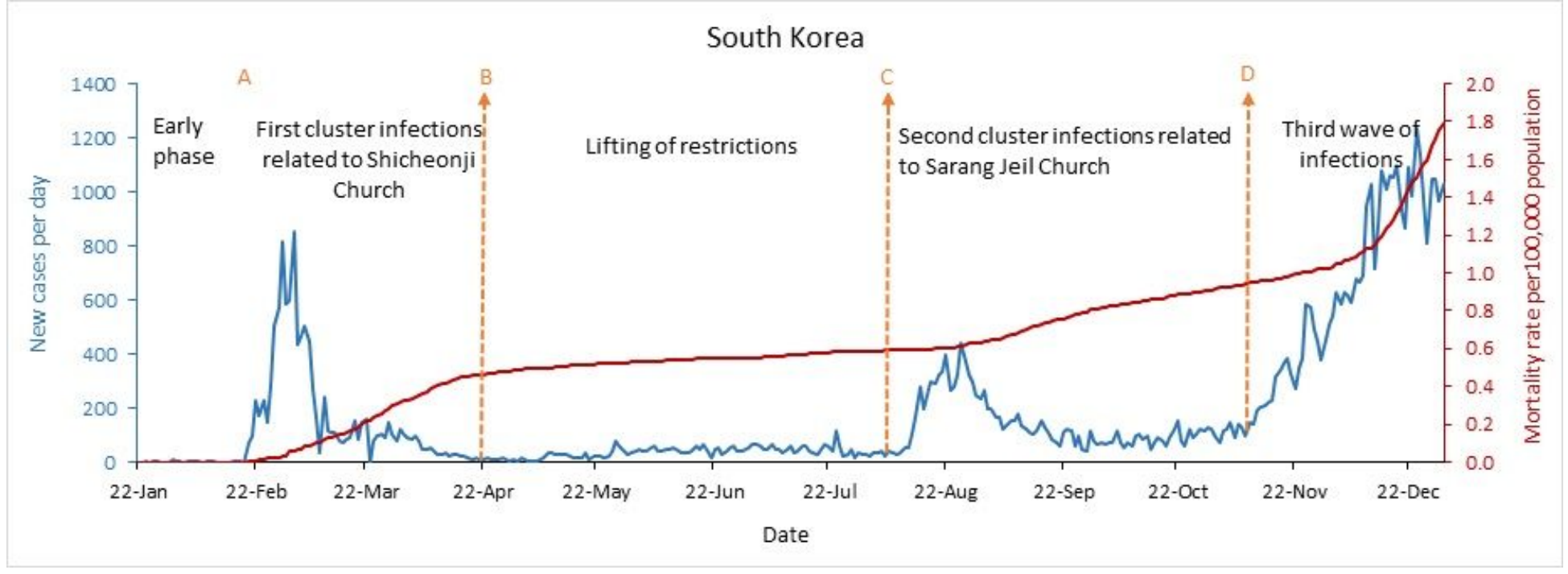

Figure 2

South Korea's COVID-19 epidemic curves and population mortality rate. Note: A Starting on February 19, 2020, cancelling mass gatherings, and various measures were taken to mass testing. B Starting on April 22 , lifting restrictions of stores, restaurants, gyms, cram schools, bars, and religious services. C Starting in August, authorities ordered 12 high-risk business categories including nightclubs, karaoke bars, buffet restaurants, and museums to cease operations; banned gatherings; imposed distancing rules; and wear masks continued to be in place. D Starting on November 9, escalating the social distancing level.

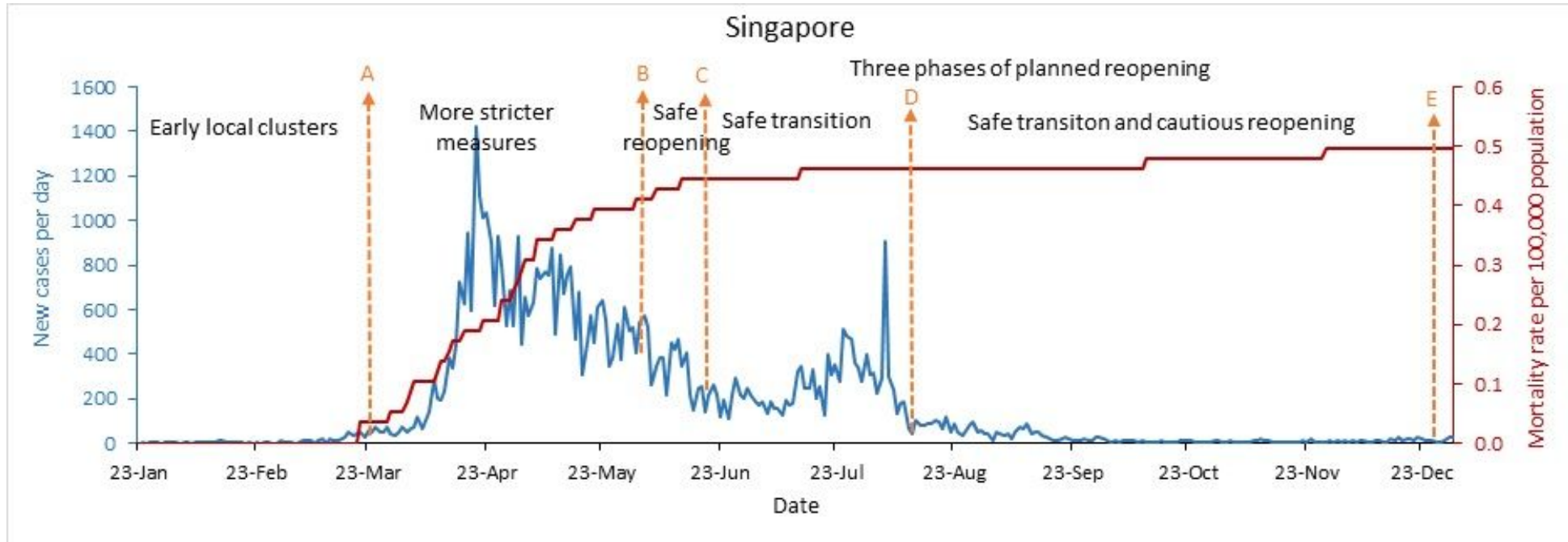

Figure 3 
Singapore's COVID-19 epidemic curves and population mortality rate. Note: A On March 24, 2020, the Multi-Ministry Task Force announced more stricter measures. B Starting on June 2, relaxing measures and implementing "Safe Reopening". C Starting on June 19, implementing "Safe Transition". D Starting in August, continuously implementing "safe transition", and cautious reopening. E Starting on December 28, implementing "Safe Nation".

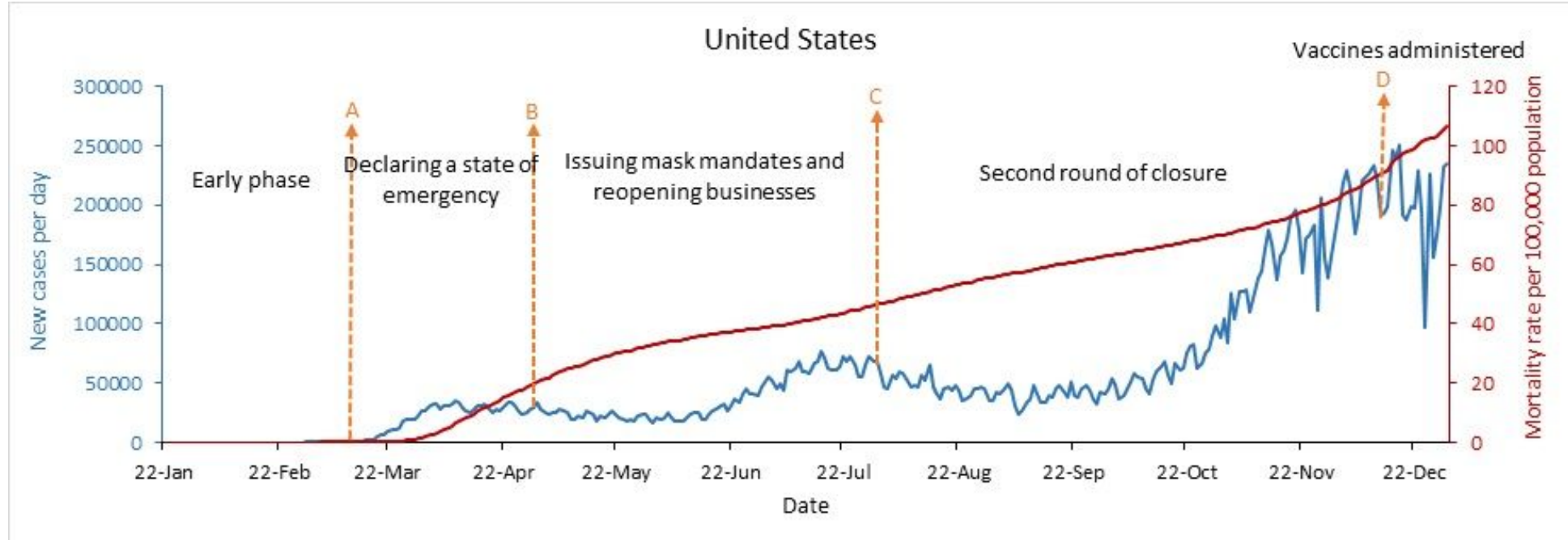

\section{Figure 4}

U.S. COVID-19 epidemic curves and population mortality rate. Note: A By March 13, 2020, the federal government escalated from a public health to a national emergency, and by March 16 all states had declared a state of emergency or a public health emergency. B Starting in May, reopening of businesses and restaurants, and masks mandate for everyone in public spaces. C Starting in August, second round of closure. D Starting on December 14, the first doses of COVID-19 vaccine were administered.

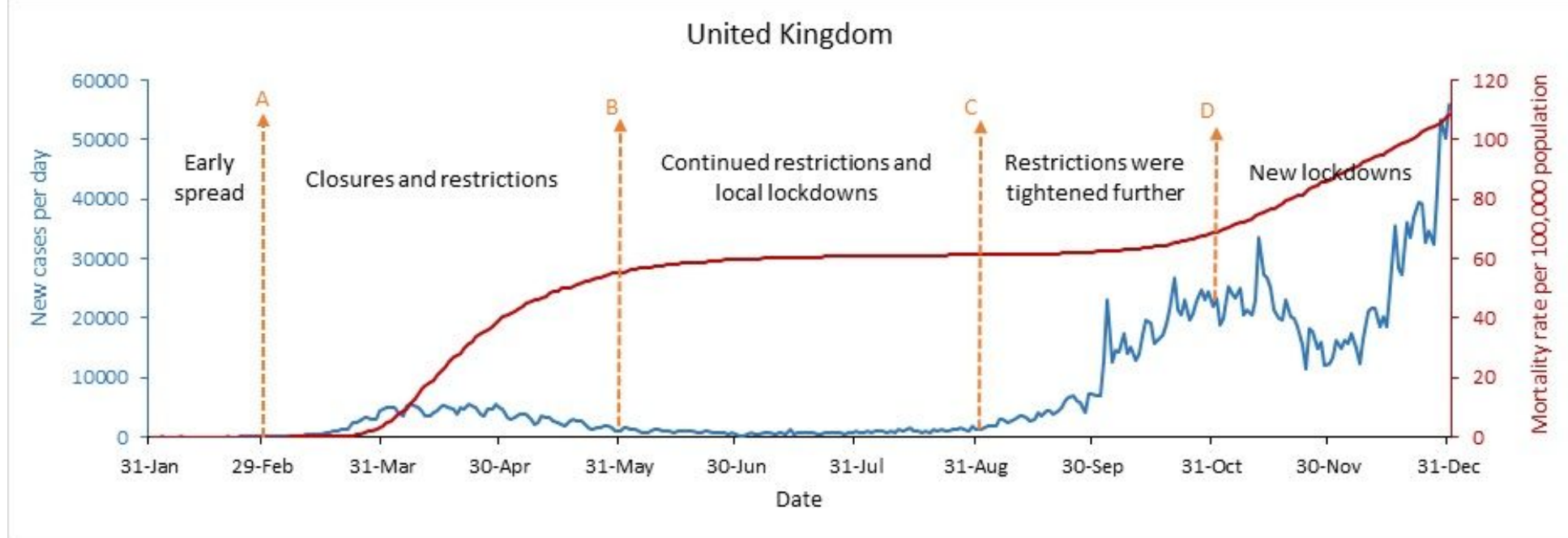

\section{Figure 5}

U.K. COVID-19 epidemic curves and population mortality rate. Note: A Starting in March, 2020, closures and restrictions. Closures and cancellations in March, lockdown continues in April, and lockdown easing begins. B Starting in June, 2020, continued restrictions and local lockdowns. Requiring individuals to self- 
isolate for 14 days upon arrival, making face masks compulsory on all public transport, and delaying lockdown restrictions. C Starting in September, restrictions were tightened further. D Starting in November, new lockdowns.

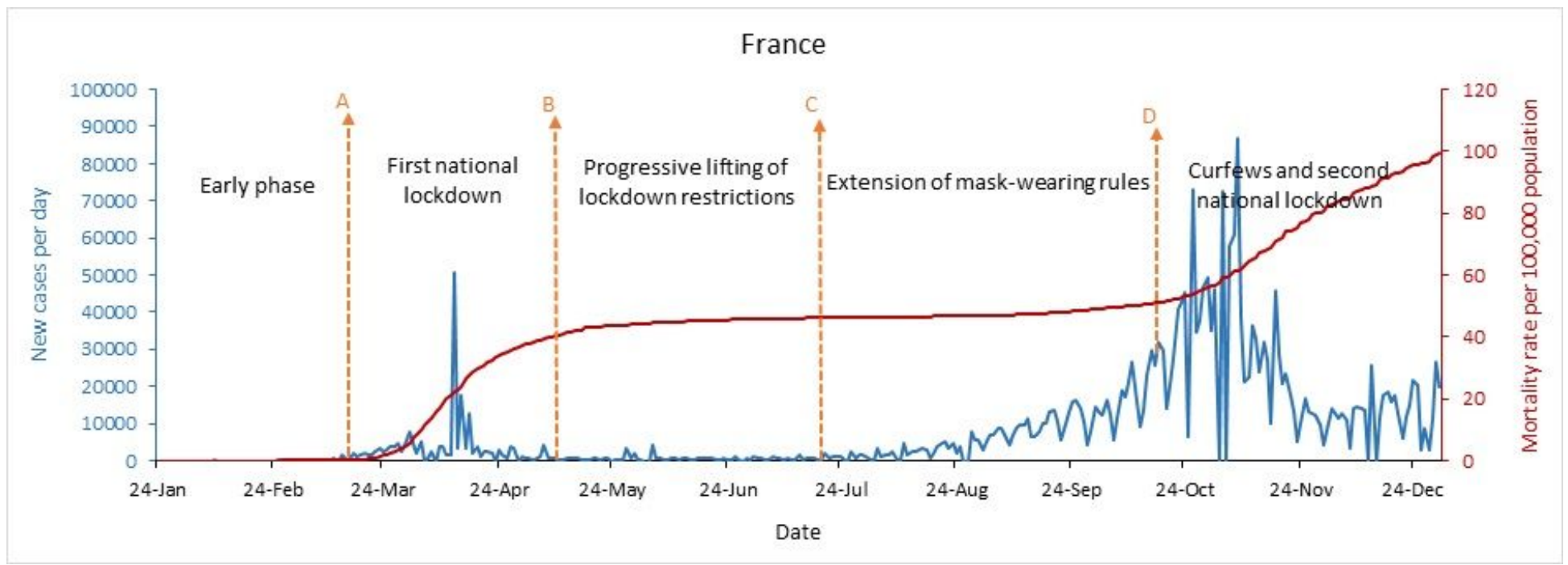

\section{Figure 6}

France's COVID-19 epidemic curves and population mortality rate. Note: A Beginning of March 17, 2020, first national lockdown. B Beginning of May 11, progressive lifting of lockdown restrictions. $C$ Beginning of July 20 , extension of mask-wearing rules. D Beginning of October 17 , curfews and second national lockdown. 